\title{
Septisk embolus
}

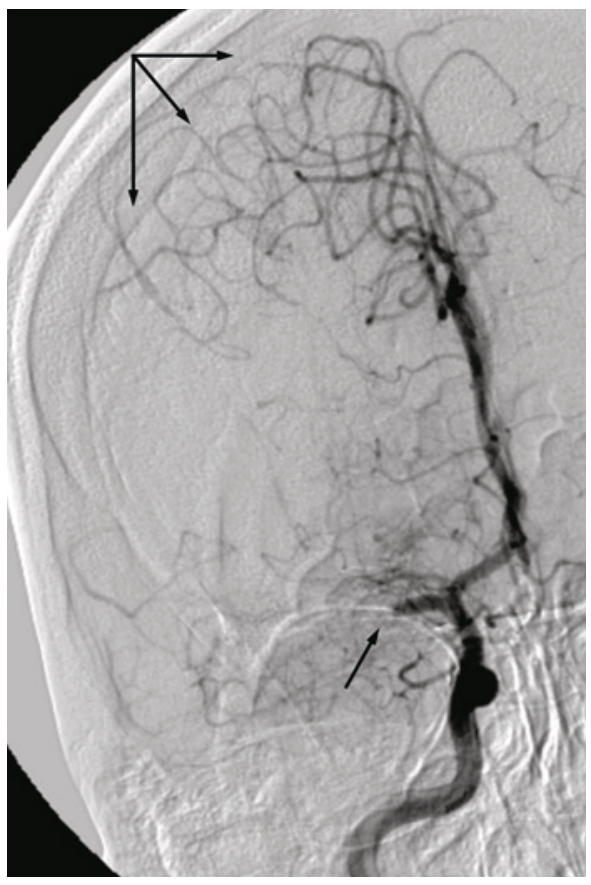

En kvinne tidlig i 30-årene ble innlagt i sykehus med akutte pareser i venstre kroppshalvdel. CT-angiografi viste okklusjon av høyre a. cerebri medias hovedstamme, og det ble startet intravenøs trombolytisk behandling. Under pågående infusjon ble hun sendt til Oslo universitetssykehus for endovaskulær behandling. Det ble utført vellykket embolektomi, med rekanalisering av arterien og rask klinisk bedring. Angiogrammene viser venstre fremre kretsløp før (venstre) og etter (høyre) prosedyren. National Institutes of Health Stroke Scale (NIHSS) ble skåret til 11 poeng ved innkomst (moderat alvorlig hjerneslag), 4 etter prosedyren (milde slagsymptomer) og 1 ved utskrivning (nær symptomfri). Av kjente vaskulære risikofaktorer bemerket vi røyking og bruk av p-piller.

Makroskopisk fremsto embolus uvanlig hard og lys i fargen. Bildet viser gramfarget snitt fra embolus med rikelig med grampositive kokker mot overflaten. Senere innleggelsesdagen ble pasienten febril, og det ble tatt blodkulturer, som ga oppvekst av streptokokker. Transøsofageal ekkokardiografi viste forandringer på mitralklaffen, med moderat insuffisiens, og det ble startet intravenøs behandling med antibiotika mot endokarditt. I ettertid fant vi at hun de siste månedene hadde oppsøkt lege flere ganger med influensaliknende feberepisoder.

Hjerneinfarkt hos unge mennesker har ofte en annen etiologi enn det som er vanligst ved
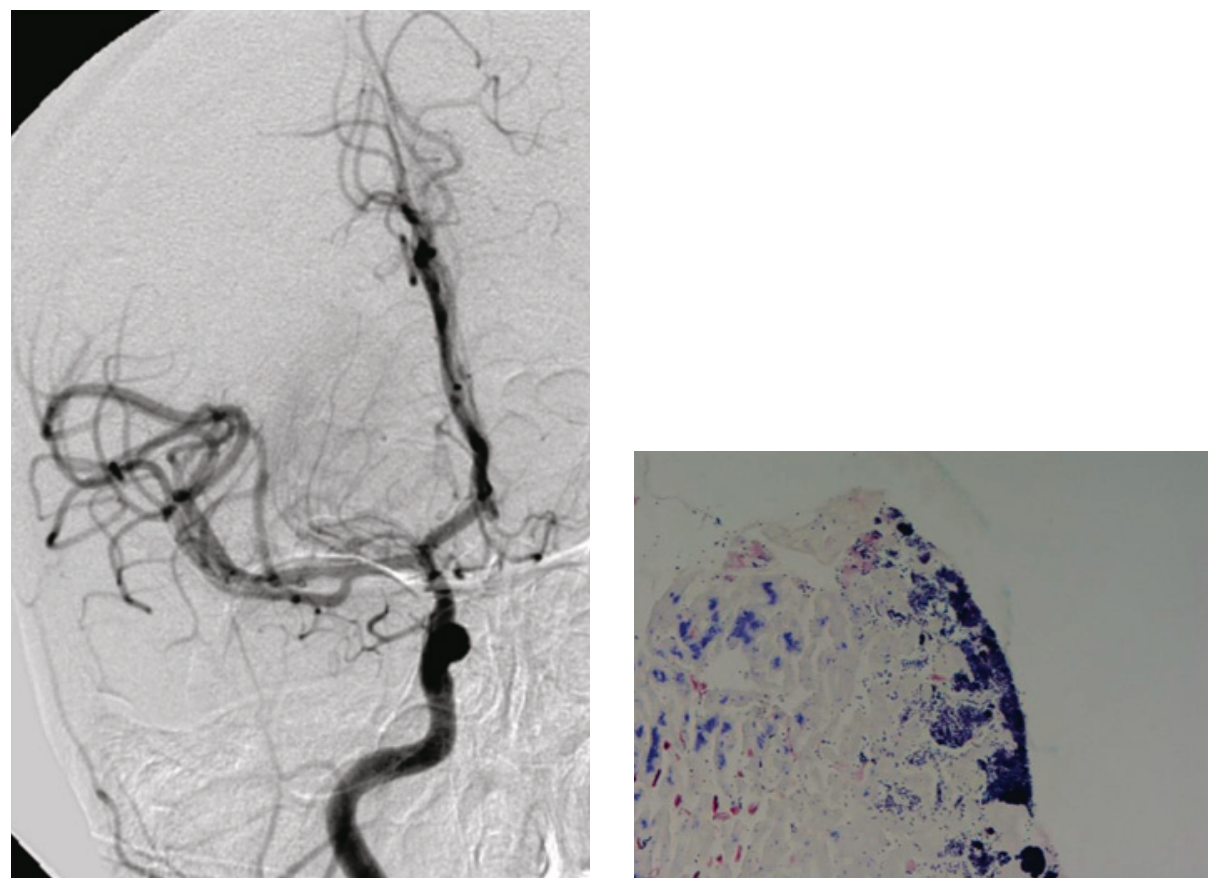

slag hos eldre. I en stor studie ble det registrert nevrologiske komplikasjoner hos en firedel av pasienter med infeksiøs endokarditt (1). Hjerneinfarkt er vanligst, men meningitt, hjerneabscess og blødninger forekommer også. Nytten av trombolytisk behandling ved septisk embolisme er ikke godt dokumentert, og indikasjonen bør vurderes individuelt ut fra klinisk skjønn (2). Endovaskulær behandling kan da være et alternativ. Risikoen for komplikasjoner til endokarditt reduseres ved tidlig diagnose og adekvat antibiotikabehandling.

Pasienten har gitt samtykke til at artikkelen blir publisert.

\section{Lasse Pihlstrøm}

laspih@ous-hf.no

Nevrologisk avdeling

\section{Bård Nedregaard}

Enhet for nevroradiologi

\section{Bård Krossnes}

Avdeling for patologi

Anne Hege Aamodt

Nevrologisk avdeling

Oslo universitetssykehus

Lasse Pihlstrøm (f. 1980) er lege i spesialisering og doktorgradsstipendiat.

Forfatter har fylt ut ICMJE-skjemaet og oppgir ingen interessekonflikter.
Bård Nedregaard (f. 1969) er spesialist i radiologi og overlege.

Forfatter har fylt ut ICMJE-skjemaet og oppgir ingen interessekonflikter.

Bård Krossnes (f. 1962) er spesialist i patologi, med spesialkompetanse i nevropatologi.

Forfatter har fylt ut ICMJE-skjemaet og oppgir ingen interessekonflikter.

Anne Hege Aamodt (f. 1972) er spesialist i nevrologi og overlege. Hun er daglig leder av ECR - forskningsinfrastruktur innen hjerneslag.

Forfatter har fylt ut ICMJE-skjemaet og oppgir følgende interessekonflikter: Hun har mottatt foredragshonorar/møtegodtgjørelse fra Bayer, BMS/Pfizer og Boehringer Ingelheim.

\section{Litteratur \\ 1. García-Cabrera E, Fernández-Hidalgo N, Almi- rante $B$ et al. Neurological complications of infec- tive endocarditis: risk factors, outcome, and impact of cardiac surgery: a multicenter observa- tional study. Circulation 2013: 127: 2272-84. \\ 2. Asaithambi G, Adil MM, Qureshi Al. Thrombolysis for ischemic stroke associated with infective endo- carditis: results from the nationwide inpatient sample. Stroke 2013; 44: 2917-9.}

Mottatt 18.12.2013og godkjent 31.1.2014. Redaktør: Matilde Risopatron Berg. 